\title{
CARA MENGAJUKAN PINJAMAN
}

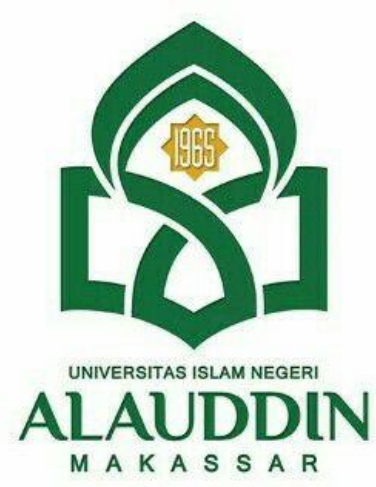

MAKALAH

Dipaparkan Pada Mata Kuliah Kewirausahaan Program Studi Perbankan Syariah Semester III Tahun 2021

Oleh :

DAHLIA

NIM. 90500120006

Dosen Pengajar:

Dra. Hj. Nuraeni Gani, MM

PROGRAM STUDI PERBANKAN SYARIAH FAKULTAS EKONOMI DAN BISNIS ISLAM UIN ALAUDDIN MAKASSAR 


\section{KATA PENGANTAR}

Puji syukur penulis panjatkan ke hadirat Allah swt. Atas rahmat dan hidayahNya sehingga penyusunan tesis ini dapat diselesaikan. Shalawat dan salam semoga tercurahkan kepada Nabi Mauhammad saw, keluarga dan para sahabatnya. tesis dengan judul: "Cara mengajukan pinjaman" ini dimaksudkan untuk memenuhi salah satu syarat lulus pada mata kuliah Kewirausahan. Penulis menyadari bahwa penyelesaian makalah ini tidak akan terwujud tanpa bantuan, bimbingan dan dukungan dari berbagai pihak.

Takalar, November 2021

Penyusun 


\section{DAFTAR ISI}

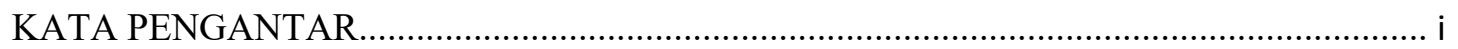

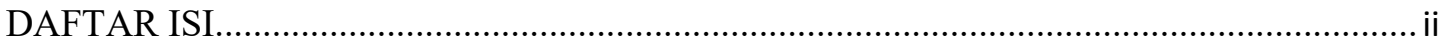

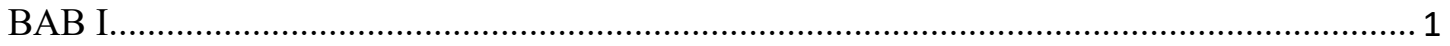

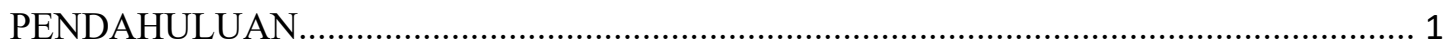

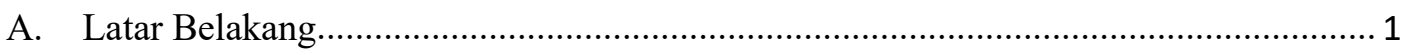

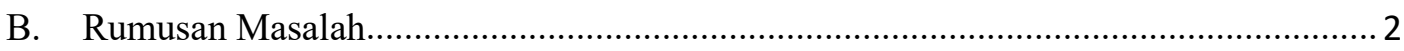

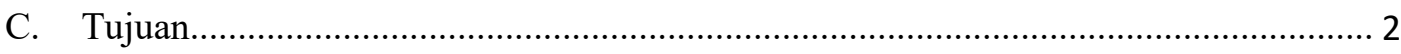

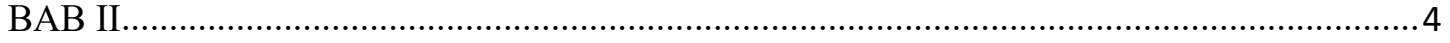

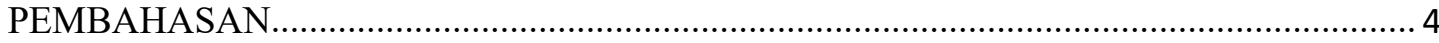

A. Persyaratan umum untuk mengajukan kredit........................................................ 4

B. persyaratan khusus menurut pekerjaan profesi untuk pegawai dan untuk karyawan

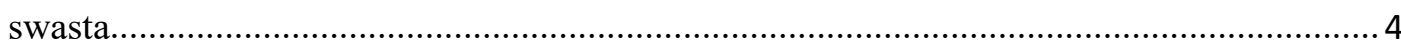

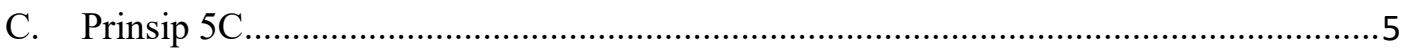

D. keunggulan dan kekurangan kredit tanpa anggunan (KTA)?.................................. 7

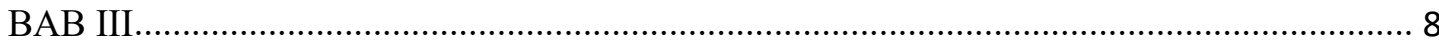

PENUTUP

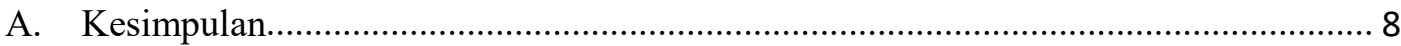

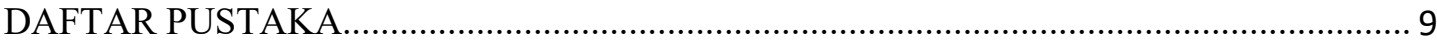




\section{BAB I}

\section{PENDAHULUAN}

\section{A. Latar Belakang}

Secara sederhana, pinjaman dapat diartikan sebagai barang atau jasa yang menjadi kewajiban pihak yang satu untuk dibayarkan kepada pihak lain sesuai dengan perjanjian tertulis ataupun lisan, yang dinyatakan atau diimplikasikan serta wajib dibayarkan kembali dalam jangka waktu tertentu. ${ }^{1}$ Kegiatan pinjam-meminjam uang adalah salah satu kebutuhan manusia dimana kegiatan ini telah dilakukan masyarakat sejak masyarakat mengenal uang sebagai alat pembayaran. Hampir semua masyarakat telah menjadikan kegiatan pinjam-meminjam uang sebagai sesuatu yang sangat diperlukan untuk mendukung perkembangan kegiatan perekonomiannya dan meningkatkan taraf kehidupannyaPihak pemberi pinjaman yang mempunyai kelebihan uang bersedia memberikan pinjaman uang kepada yang memerlukannya. Sebaliknya, pihak peminjam berdasarkan keperluan atau tujuan tertentu melakukan peminjaman uang tersebut. Secara umum dapat dikatakan bahwa pihak peminjam meminjam uang kepada pihak pemberi pinjaman untuk membiayai kebutuhan yang berkaitan dengan kehidupan sehari-hari atau untuk memenuhi

${ }^{1}$ (Ardiyos, 2004) 
keperluan dana guna pembiayaan kegiatan bisnisnya. Pinjam-meminjam uang suatu kegiatan yang sudah merupakan bagian dari kehidupan masyarakat saat ini. ${ }^{2}$

\section{B. Rumusan Masalah}

Berdasarkan latar belakang yang telah penulis uraikan, maka pokok masalah yang diangkat dalam penelitian ini adalah bagaimana Cara Mengajukan Pinjaman? Adapun sub masalah yang akan dibahas adalah:

1. Bagaimana persyaratan umum untuk mengajukan kredit?

2. Bagaimana persyaratan khusus menurut pekerjaan profesi untuk pegawai dan untuk karyawan swasta?

3. Apa yang dimaksud dengan Prinsip 5C?

4. Apa yang dimaksud dengan kredit tanpa anggunan (KTA)?

5. Apasajakah keunggulan dan kekurangan kredit tanpa anggunan (KTA)?

\section{Tujuan}

Sejalan dengan rumusan masalah yang telah dituangkan, maka tujuan penulisan ini adalah sebagai berikut:

1. Untuk mengetahui persyaratan umum untuk mengajukan kredit?

2. Untuk mengetahui persyaratan khusus menurut pekerjaan profesi untuk pegawai dan untuk karyawan swasta?

3. Untuk mengetahui Prinsip 5C?

4. Untuk mengetahui yang dimaksud kredit tanpa anggunan (KTA)?

2 (Bahsan, 2008) 
5. Untuk mengetahui keunggulan dan kekurangan kredit tanpa anggunan (KTA)? 


\section{BAB II}

\section{PEMBAHASAN}

\section{A. Persyaratan umum untuk mengajukan kredit}

Prinsipnya, bank hanya akan memberi kredit pada orang yang dipercaya. Oleh sebab itu, hal yang perlu Anda lakukan adalah meyakinkan pihak bank agar percaya pada Anda. Caranya? Penuhi semua persyaratan yang diminta. Seperti kami ringkas dari beberapa situs perbankan nasional, bank selanjutnya akan membedakan debitur perorangan ini dalam tiga golongan, yakni wirausahawan, karyawan, dan profesional, sesuai profesi masing-masing debitur. Persyaratan yang diminta umumnya sama, yakni:

- Mengisi formulir aplikasi

- Fotocopy identitas diri (KTP, SIM, Paspor)

- Fotocopy akta nikah (bagi yang telah menikah)

- Fotocopy Kartu Keluarga (KK)

- Fotocopy buku tabungan beberapa bulan terakhir

B. persyaratan khusus menurut pekerjaan profesi untuk pegawai dan untuk karyawan swasta

1. persyaratan khusus menurut pekerjaan profesi untuk pegawai yaitu : 
- Fotocopy dan asli Kartu Pegawai (Karpeg) serta tabungan dan asuransi pensiun (TASPEN) bagi pegawai

- Fotocopy dan asli SK CPNS

- Fotocopy dan asli SK PNS

- Fotocopy dan asli SK pangkat terakhir

- Fotocopy dan asli SK Kenaikan Gaji Berskala terakhir

- Daftar gaji kolektif

2. persyaratan khusus menurut pekerjaan profesi untuk Karyawan swasta yaitu :

- Slip gaji dan Surat Keterangan Bekerja dari Perusahaan (bagi karyawan swasta)

- Surat keterangan perincian penghasilan untuk wirausahawan yang meliputi fotocopy rekening koran/giro atau buku tabungan di Bank manapun selama 3-6 bulan terakhir dan data keuangan lain seperti neraca keuangan, laporan laba rugi, catatan penjualan dan pembelian harian, serta data pembukuan lainnya.

\section{Prinsip 5C}

Prinsip 5C sebagai dasar Credit Analyst untuk menyetujui atau menolak pengajuan pinjaman. Berikut adalah prinsip $5 \mathrm{C}$ yaitu :

1) Character (karakter calon debitur) 
- Prinsip ini dilihat dari segi kepribadian calon debitur.

- Merupakan hasil wawancara antara Customer Service kepada calon debitur berupa latar belakang, kebiasaan hidup, dll.

2) Capacity (kemampuan untuk mengembalikan)

Prinsip ini menilai calon debitur atas kemampuannya dalam menjalankan keuangan, baik sebagai karyawan maupun pengusaha.Melihat apakah calon debitur pernah mengalami permasalahan keuangan sebelumnya atau tidak.

3) Capital (kondisi finansial)

Prinsip ini terkait dengan kondisi aset dan kekayaan yang dimiliki oleh calon debitur.

4) Collateral (barang jaminan)

Prinsip ini diperhatikan para calon debitur andaikan mereka tidak dapat memenuhi kewajibannya dalam membayar cicilan kredit.

5) Condition (kondisi ekonomi)

Prinsip ini dipengaruhi faktor di luar Bank ataupun calon debitur. Artinya kondisi perekonomian suatu daerah atau negara sangat berpengaruh. Prinsip ini biasa disebut prinsip kehati-hatian dalam menganalisis potensi resiko terganggunya pemasukan calon debitur akibat kondisi ekonomi.

\section{A. kredit tanpa anggunan (KTA)?}

- Kredit Tanpa Agunan merupakan model pinjaman yang tidak memerlukan jaminan atau agunan dari nasabah. Pinjaman ini ditujukan kepada nasabah 
yang membutuhkan dana cepat, tapi tidak memiliki aset berharga seperti kendaraan pribadi atau rumah untuk dijaminkan kepada bank.

- KTA dapat digunakan untuk keperluan yang mendesak, seperti renovasi rumah, biaya pendidikan anak, pengobatan, modal usaha, pernikahan, dll.

\section{D. keunggulan dan kekurangan kredit tanpa anggunan (KTA)?}

1) Keunggulan kredit tanpa anggunan yaitu :

- Persyaratan pengajuan yang lebih mudah dan proses pencairan yang cepat.

- Tidak memerlukan aset sebagai jaminan pinjaman.

- Dapat digunakan untuk kebutuhan apapun.

- Suku bunga tetap selama masa pinjaman.

- Tenor atau periode cicilan cukup fleksibel mulai dari 12 bulan hingga 60 bulan.

- Plafon pinjaman cukup besar hingga Rp.300.000.000,-

2) Kekurangan kredit tanpa anggunan yaitu :

- Periode pinjaman yang relatif lebih pendek dibanding pinjaman beragunan maksimal 5 tahun.

- Harus memiliki kartu kredit sebagai salah satu syarat pengajuan 


\section{BAB III}

\section{PENUTUP}

\section{A. Kesimpulan}

Secara sederhana, pinjaman dapat diartikan sebagai barang atau jasa yang menjadi kewajiban pihak yang satu untuk dibayarkan kepada pihak lain sesuai dengan perjanjian tertulis ataupun lisan, yang dinyatakan atau diimplikasikan serta wajib dibayarkan kembali dalam jangka waktu tertentu. Bank dalam penyaluran kredit harus memperhatikan prinsip 5C, yaitu: $3 \quad$ 1) Character (watak) $\quad$ 2) Capacity (kemampuan) 3) Capital (modal) 4) Collateral (jaminan) 5) Condition of economy (kondisi ekonomi). 


\section{DAFTAR PUSTAKA}

Ardiyos. (2004). Kamus Besar Akuntansi. Bandung: Alfabetis.

Bahsan, M. (2008). Hukum Jaminan Dan Kredit Perbankan Syariah. Jakarta: Raja Grafindo Persada. 